British Journal of Education

Vol.8, Issue 3, pp.41-75, March 2020

Published by ECRTD- UK

Print ISSN: ISSN 2054-6351

Online ISSN: ISSN 2054-636X

\title{
THE PERSPECTIVES AND EFFECTIVENESS OF AUTHENTIC MATERIALS IN LISTENING COMPREHENSION OF SAUDI UNIVERSITY STUDENTS
}

\author{
Arafat Hamouda \\ Assistant Professor, Assuit University, Egypt \\ Email: arafathamouda62@Gmail.com
}

\begin{abstract}
Due to the lack of exposure to the use of English real language beyond the classroom time, specifically the use of authentic listening materials in the listening lessons, many students have great difficulty understanding the real language produced by native speakers or the authentic ones they hear. However, far too little attention has been paid to the use of authentic listening materials in the Saudi EFL context. To address such critical gab, the current study aims at investigating the effect of using authentic materials on the listening comprehension ability of Saudi EFL subjects. It also explores students' attitudes and reactions towards the use of authentic listening materials. The participants of this study were students majoring in English Language Translation Department at Qassim University. After random selection, 44 students from the fourth level took part in this study. The participants were randomly divided into two equal groups: the experimental group consisting of (22) students and the control one consisting of (22) other students. The control group underwent listening activities through inauthentic materials, while the experimental group was exposed to and received a combination of inauthentic and authentic listening materials. Data collection instruments were two listening comprehension tests, interviews and questionnaires. Results of post-tests revealed the experimental group's listening comprehension ability improved significantly more than that of the control group. Analysis of the interviews and the questionnaire also revealed EFL students' satisfaction and positive attitudes toward the use of authentic listening materials. This means that the use of authentic materials helps bring the contact to life, and ultimately makes learning and using language more meaningful and easier for students. These results again verified the value of authentic material-use in the classroom, specifically in regards to teaching listening skills. The positive findings of this study also indicate the need for authentic materials to gain a larger role in the EFL classroom and for more research to be carried out in other areas of language skills. Hence, using authentic materials in teaching English in tertiary level needs more attention in their use in the classroom.
\end{abstract}

KEYWORDS: authentic material, non-authentic materials, listening comprehension ability, attitude, EFL learners 
British Journal of Education

Vol.8, Issue 3, pp.41-75, March 2020

Published by ECRTD- UK

Print ISSN: ISSN 2054-6351

Online ISSN: ISSN 2054-636X

\section{INTRODUCTION}

It is undeniable that English is one of the most important and widespread languages in the world. The popularity of English around the world results to the increasing demand of learning this language as a means of communication (Al-Sobhi and Preece, 2018). To be able to communicate means to express thoughts, feelings, and information effectively through the four language skills. One of the most useful skills used by second language learners is listening because the evidence shows that we acquire language through our listening to the interactional conversations (Polat and Eristi 2019). Listening also plays an important role in daily communication. Similar to this, Lina (2015) sees that listening is also the fundamental skill because it provides the aural input which serves as the basis for the acquisition of the language.

In a language classroom, listening ability plays a momentous role in the development of other language skills. According to Al-Nafisah (2019), listening is the most demanding of all the language skills, as it is a vital discovery that enables students unmask creative ways in which language is pronounced and comprehended. Listening can help students build vocabulary, develop language proficiency, and improve language usage (Abu Hatab, 2010). Ghaderpanahi (2012) asserts that "developing proficiency in listening comprehension is the key to achieving proficiency in speaking". Similarly, Dewi (2018) considers listening as an active process because it involves speaker's accent, pronunciation, grammar and vocabulary. Listening also plays a great role in our daily communication. You listen to develop relationships, gather and interpret information, and deliver messages. Listening in deep detail means paying attention not only to the words, but how the use of language and voice, pronunciation, rate of speech which means to understand what a speaker means by his /her messages.

In spite of its importance, listening has been considered one of the most challenging and difficult skills to develop due to the different accents and pronunciations of English language around the world (Brownell 2013 and Ghaderpanahi 2012). This is especially the case of an English-as-aforeign-language (EFL) situation in which the English language is taught as a subject at school and used only inside, but not outside, the classroom. The students, therefore, are not accustomed to hearing the language as it is produced by native speakers for native speakers. Instead, students are exposed to the modified and unnatural language used in the classrooms. As a result, students fail to comprehend the real language used by native speakers or the authentic one they hear. They have great difficulty understanding English spoken to them when they come into contact with native speakers of the language. 
British Journal of Education

Vol.8, Issue 3, pp.41-75, March 2020

Published by ECRTD- UK

Print ISSN: ISSN 2054-6351

Online ISSN: ISSN 2054-636X

Due to the challenges and difficulties that EFL/ ESL students encounter when hearing the authentic language used by native speakers, numerous studies have been conducted to reveal the reasons of such big problem. For example, Al Asmari and Gulzar (2016) and Sabet and Mahsefat (2012) found out more than one reason for ESL and EFL students' agony when hearing the real language used by native speakers. One of the main reasons was the lack of 'exposure' to real life situation for 'natural' development of language is a big problem. Another reason deals with layers of sound. In real-life situations, native speakers speak over each other, at different volumes and speeds and often with frequent interruptions (Ghaderpanahi 2012). A third reason was accents. While written English is pretty much the same the world over, there are a myriad of accents in spoken English which can make it even more difficult for the learner to follow a conversation. A fourth reason was that the edited materials that are proposed for teaching listening skills in the classroom do not present the real situation of the language. Students need to listen to the kind of authentic English materials as the same kind that they will actually encounter in real life. The real language is not always grammatically correct and is sometimes imprecise or faltering. It may reflect a kind of genuine, natural and spontaneous unscripted spoken language that contains hesitations, repetitions, improvisations, fillers and so on; which can take different forms (interviews, lectures, discussions...etc.) (Mousavi and Iravani, 2012).

Due to the above-mentioned reasons that lead to students' failure to comprehend the real-life conversation produced by native speakers, it becomes necessary for teachers and educators to think of ways of bringing the real world into the foreign language classroom to enhance listening skills. One way of bringing the real language into the ESL/EFL classroom is to apply real language or authentic listening materials in the classroom such as Radio/TV programs, videos, films, novels, short stories, weather forecasts and so on (Gilmore, 2007).

The term "authentic materials" is defined as materials which are designed for native speakers; they are real texts; designed not for language students, but for the speakers/ listeners of the language (Al-Musallam, 2009). The most common definition for authentic materials is unaltered texts that are generated by native speakers and for native speakers (Mousavi and Iravani, 2012). Authentic materials are also defined as oral and written language materials used in daily situations by native speakers of the language (Polat and Eristi, 2019). According to (Ali and Celik, 2019), "authentic listening materials" refer to oral and written language materials used in daily situations by native speakers of the language. The materials that are used such as newspaper articles, magazines, videos, TV series, television advertisements, radio programs and real-life conversations can help the students to become familiar with the target language. 
British Journal of Education

Vol.8, Issue 3, pp.41-75, March 2020

Published by ECRTD- UK

Print ISSN: ISSN 2054-6351

Online ISSN: ISSN 2054-636X

It is worth mentioning that authentic materials are very useful in second language classroom that can keep students informed about what is happening in the world, they also expose students to real discourse which helps them to understand the native speakers' correct language as pronunciations, stress, rate of speech ........ etc. An advantage of introducing authentic materials at an ESL/EFL classroom is to help students become familiar with the target language (Dewi, 2018). The use of authentic materials in ESL teaching and learning appears to be worthwhile (Al-Nafisah, 2019; Mohammed, 2019; Ali and Celik; 2019; Polat and Eristi, 2019). Implementing authentic speech in classroom listening allows students to have "immediate and direct contact with input data which reflect genuine communication in the target language" (Gilmore, 2007).

The importance of introducing authentic materials at an ESL/EFL classroom attracts the attention of many researchers who have conducted a plenty of empirical studies with the aim of investigating the effects of the use of authentic listening materials among EFL/ ESL students in different settings (i.e. Abdelhafez and Abdallah, 2015; Bahrani and Sim, 2012; Mohammed, 2019 and Bekena, 2011). Such studies have confirmed the positive results obtained by learners who have opportunities to interact with and utilize authentic texts. The previous studies have reached to a conclusion which suggests that applying authentic materials has improved the communicative ability of the learners.

Despite the significance of authentic materials that has been stressed in the previous studies conducted in other contexts (e.g., Otte, 2006; Miller, 2005; Dewi, 2018), the in-class use of authentic listening materials has not yet received the much-required attention in the Saudi EFL context. Therefore, EFL students' attitudes toward the use of authentic materials in their listening classes have been an issue that might not have received sufficient attention in the context of Saudi EFL classrooms. Consequently, the present study seeks to address this gab and find out the effectiveness of using authentic listening materials on listening comprehension achievement among English language majors at Qassim University because of multiplicity of reasons as discussed later.

\section{Statement of the Problem}

Listening as one of the most pivotal skills has been given more attention due to the momentous role it plays in the development of other language skills. Listening can help students build vocabulary, develop language proficiency, and improve language usage (Dewi, 2018). Mousavi and Iravani (2012) assert that "developing proficiency in listening comprehension is the key to achieving proficiency in speaking". Listening skills are also the basis for the development of all other skills; and they are the main channel through which students make initial contact with the target language and its culture (Ali and Celik; 2019). 
British Journal of Education

Vol.8, Issue 3, pp.41-75, March 2020

Published by ECRTD- UK

Print ISSN: ISSN 2054-6351

Online ISSN: ISSN 2054-636X

However, listening has long been considered the most challenging and difficult skill in high level of education at Saudi university level. During his work as assistant professor in teaching listening courses more than ten years, the researcher of this study has noticed that Saudi English majors have problems in listening comprehension. Students have great difficulty in comprehending the real language produced by native speakers or the authentic one they hear. Some students often feel panic when they hear the English language on television, radio, or in situations in which speech is fast and nothing is repeated. In discussing such problem with other teachers who teach the same course, they attribute the students' agony in listening comprehension to the lack of exposure to authentic listening material which reflects the real language that native speakers use in their daily communication. Teachers also add that there has been a gap between the language taught in the classroom and the language used in real life. For example, English conversation taught in the textbooks and the classroom tends to be unable to represent the actual model of how it is conducted in real life of the native speakers. In the same vein, some researchers believe that EFL students can't understand the real language produced by the native speakers because most of the instructional materials used in the classrooms are simplified and unnatural (e. g. Al Asmari and Gulzar, 2016 and Sabet and Mahsefat, 2012; and Al-Musallam, 2009). Saudi students are rarely accustomed to listening to native English language speakers, which puts them in great difficulty in comprehending English language spoken with its usual pace and pitch. Without having an actual exposure to authentic language, it will be very difficult for EFL students to comprehend what native speakers meant by their speech. In order to understand the real language produced by the native speakers, students must experience the language as it is used for real communication by native speakers. As a result, it becomes necessary for teachers and educators to think of ways of bringing the real world into the foreign language classroom to enhance listening skills. One way of bringing the real language into the classroom is to use authentic listening materials in the ESL classroom such as Radio/TV programs, videos, films, and so on (Losada, Insuasty, and Osorio 2017).

Many empirical studies have been conducted to examine the significance of the authentic listening materials and the results revealed the positive impact on learners who were exposed to authentic texts. For example, Al-Nafisah (2019) and Bahrani and Sim (2012), found that aural language development was improved when the practice incorporates authentic materials. Polat and Eristi (2019) reach to the conclusion that exposing learners to authentic materials is indispensable, because of the rich language input they provide. Moreover, Mohammed (2019) examined the impact of aural authentic texts on listening comprehension abilities of ESL students at the university level. He found that students' listening comprehension abilities and motivation 
British Journal of Education

Vol.8, Issue 3, pp.41-75, March 2020

Published by ECRTD- UK

Print ISSN: ISSN 2054-6351

Online ISSN: ISSN 2054-636X

increased after exposure to authentic materials. Similarly, Ali and Celik (2019) assert that using authentic listening materials has great influence on developing listening comprehension.

Despite the positive effects of utilizing authentic listening materials on developing listening comprehension in ESL and EFL settings, there has been relatively little empirical research in this specific area in Saudi contexts (Al-Musallam, 2009; Al-Nafisah, 2019). Therefore, the aforementioned studies ascribe the students' difficulty in listening comprehension to the lack of exposure to authentic listening material. Because of the noticeable lack of adequate exposure to authentic listening materials and dearth of studies with regard to this issues in the Saudi context, and more specifically in the department of English, the present research seeks to investigate the impact of using authentic listening materials on listening ability among Qassim University English majors, and explore deeply the students' attitudes and reactions to the use of authentic listening materials in classrooms.

\section{The Purpose of the study}

To fill in the gap, the present study is primarily intended to:

1 To investigate the impact of using authentic listening materials on listening comprehension ability among Qassim University English majors

2 To explore deeply the students' attitudes and reactions toward the use of authentic listening materials in classrooms

\section{Research questions}

The following questions will drive the present study.

1.What are the impacts of authentic aural materials on the Saudi EFL students' listening comprehension ability?

2. What are the attitudes and reactions of EFL students toward the use of authentic listening materials in developing the listening listening comprehension ability?

\section{Hypotheses of the Study}

Based on the research questions and the nature of the study, the hypotheses are:

-There is no significant difference between means of scores obtained by the experimental group (who were taught English listening course through authentic and non-authentic listening materials) and the control group (who were taught listening course through the non-authentic listening materials) in terms of their overall listening comprehension in the pre-test.

-There is no significant difference between the pre- and post-test mean scores of overall listening comprehension for the control group.

-There is significant difference between the pre- and post-test mean scores of overall listening comprehension for the experimental group and this difference is in favor of the post-test. 
British Journal of Education

Vol.8, Issue 3, pp.41-75, March 2020

Published by ECRTD- UK

Print ISSN: ISSN 2054-6351

Online ISSN: ISSN 2054-636X

-There is significant difference between means of scores obtained by the experimental and the control group in terms of their overall listening comprehension in the post-test and this difference is in favor of the experimental group.

-Students have positive attitudes towards using authentic listening materials.

\section{Significance of the Study}

The findings of this research will be important to guide and provide great contributions for teachers, students, decision-makers, curriculum development experts, and all the stakeholders in the field of foreign language teaching and learning. Findings from this study will help each of the following sections:

1. English Departments: It is supposed to guide the department staff to the urgent need of using the aural authentic materials in teaching listening courses. So, listening course description may be modified in the light of the study results.

2. Course Designers: The current study is intended to flash and raise many crucial issues in the design of English listening courses to those who are responsible for preparing courses. It is expected to benefit them regarding all aspects of the curriculum.

3. Lecturers: The findings of this study would be of value to teacher education coordinators seeking to determine more beneficial materials for the teaching and learning of English.

4. Students: It magnetizes the students to join a new way of learning. Their readiness and motivation will be increased through the instructional variety presented via the aural authentic materials.

5. The findings of this study will hopefully contribute to the improvement of practices for teaching listening in Saudi English classes.

\section{Study Variables}

The study contained the following two variables.

\section{An independent variable}

The independent variable refers to the treatment implemented in this study (the use of authentic listening materials implemented with the experimental group versus the use of non-authentic materials received by the control group).

\section{A dependent variable}

Dependent variables were the subjects' scores on the listening comprehension test and the scores of their responses to the items of the attitudinal questionnaire.

The connection between these two variables will be evident when the results show the effect the independent variable (authentic listening material) has over the dependent variable (listening competence of the students). 
British Journal of Education

Vol.8, Issue 3, pp.41-75, March 2020

Published by ECRTD- UK

Print ISSN: ISSN 2054-6351

Online ISSN: ISSN 2054-636X

\section{METHODOLOGY}

\section{Research Approach}

The current study follows an experimental approach that is designed to offer answers to the main research questions and provides more information related to the impacts of authentic aural materials on the Saudi EFL students' listening comprehension ability.

\section{Participants}

Forty-four Saudi undergraduate students of Qassim University majoring in English Language and Translation were recruited to participate in the particular study. The subjects were between nineteen and twenty-one years. They were all male. The participants of the current study were taking a listening class during the first semester of the academic year 2018/2019. The participants of the study were randomly divided into two groups; experimental group (No.22) and control group (No.22). The experimental group was exposed to authentic and inauthentic listening materials, while the other one was exposed to the inauthentic listening materials (control group). It is important to mention that both of the groups were evaluated at the beginning and at the end of the term in order to obtain the data that was necessary to carry out the investigation. Both groups were taught by the same teacher in order to prevent the different teacher effect on the performance of the students.

All participants are Arabic-native speakers. They were assured their responses will remain confidential and will be used for academic purposes only.

\section{Materials}

To determine the comparative effectiveness of authentic or inauthentic materials, two series of materials from either were selected. Authentic materials are defined as those which are produced by native speaker or materials in which produced for non-pedagogical purposes. Inauthentic materials are those materials which are produced for teaching purposes.

The researcher selected and prepared the authentic materials, and additional activities to use in the English lessons. All materials and activities were prepared regarding the needs, interests and proficiency level of the students participating in the study. The researcher selected the authentic listening materials based on the following criteria:

1. Suitability of content to Students' Needs;

2. Topics' Familiarity;

3. cultural appropriateness;

4. linguistic demands;

5. cognitive demands;

6. logistical considerations: e.g. length, legibility/audibility; 
British Journal of Education

Vol.8, Issue 3, pp.41-75, March 2020

Published by ECRTD- UK

Print ISSN: ISSN 2054-6351

Online ISSN: ISSN 2054-636X

7. To be in accordance with the course objectives

8. Language Clarity.

9. Variety of Sources

\section{Research Instruments}

A variety of data-collecting instruments were employed to collect both qualitative and quantitative data to serve the purpose of answering the research questions. A mixed-method approach was applied with listening comprehension test, questionnaire, and interview used for triangulation. To increase the validity of the results obtained, the method utilized for data collection in this research was based on triangulation. Triangulation is often used to mean bringing different kinds of evidence to bear on a problem (Dewi, 2018).

Thus, if you have access to interview data, questionnaire data, and test data, your analysis is likely to be much sounder than if you rely on only one source of evidence.

To gather pertinent data for this study, the following research instruments were utilized.

\section{A listening comprehension test}

According to Losada, Insuasty, and Osorio (2017), listening comprehension test can effectively evaluate students' listening. Thus, the researcher designed two listening comprehension tests to be used as an assessment tool to assess the experimental and the control groups' listening comprehension skills before and after the application of the experiment. In the first session, before students received any instruction, all the students, the experimental group and the control groups, sat for a pre-test to decide their actual level before being taught. More specifically, students were given a pretest, which showed where the students were (academically) in their listening comprehension test skills prior to implementation.

A two-part pretest was administered. This pretest included a part for authentic and a part for nonauthentic listening materials (reliability was found through KR-21 formula). The authentic part was compiled by the researchers and it consisted of 25 around two- or three-minute authentic radiotapes taken from BBC or VOA. For non-authentic listening materials, the participants were instructed in usual listening materials selected from the listening part of Interaction and similar English programs like Headway and American Streamline. The contents of the listening materials seem to be social and non-technical. The listening materials were mostly in the form of minidialogues or mini-lectures. Each mini-dialogue or mini-lecture was followed by two or three listening comprehension questions. This test helped the researcher keep track of the learners' listening improvement. 
British Journal of Education

Vol.8, Issue 3, pp.41-75, March 2020

Published by ECRTD- UK

Print ISSN: ISSN 2054-6351

Online ISSN: ISSN 2054-636X

The post-test in this study was another sample test of listening comprehension for non-authentic listening material and a similar (described in pre-test) version of authentic radio-tape listening materials to determine the efficacy of the non-authentic and authentic radio-based treatment on the listening comprehension of EFL learners. The post-test had nearly the same characteristics in time, number, and content of the listening comprehension task used in pre-test. Both tests (pre- and posttests) were made up of 50 items and each took about 50 minutes (one minute for each item). Time (5 minutes) was also given to participants to check their answers and transfer them to the answer sheet at the end of the test. For reliability purposes, the participants' listening test was scored by two ratters. The researcher assessed the validity and reliability of the listening comprehension test and found out that it is valid and reliable for the study.

\section{Questionnaire}

The second research instrument was the questionnaire. It tried to pinpoint the students' attitudes regarding the benefits students get from being exposed to authentic listening materials. The researcher consulted many related research studies including the ones conducted in the EFL context (such as Sabet \&Mahsefat, 2012; Al-Musallam, 2009) to collect data to develop a suitable questionnaire to elicit the responses of English-major undergraduates of Qassim University related to the use of authentic listening materials. The questionnaire was administered at the end of ninth week of the treatment when the students of the experimental group had completed the experiment. The participants were asked to respond to a Likert-scale agree- disagree questionnaire.

\section{Semi-structured Interview}

To gather pertinent data for the study, semi-structured interview questions were prepared and conducted with ten students of the experimental group to gather information about their opinions and comments on the use of authentic listening materials, the sources, the availability of these materials in the college and how they select and utilize them in their listening instruction.

\section{Samples of the interview questions}

1. Would you support the use of authentic materials in your listening classes? Why or why not?

2. Which factors, if any, do you think would hinder the use of authentic listening materials in EFL instruction?

3. How do you think EFL teachers at Saudi Colleges can make appropriate use of authentic materials for listening instruction?

4. Do you think that you can listen to and enjoy authentic materials? What do you need in order to succeed in dealing with authentic materials?

5. What types of activities would facilitate your comprehension of authentic materials? 
British Journal of Education

Vol.8, Issue 3, pp.41-75, March 2020

Published by ECRTD- UK

Print ISSN: ISSN 2054-6351

Online ISSN: ISSN 2054-636X

\section{Data collection and Statistical Analysis}

The data collected through research tools (i.e. listening comprehension test, questionnaire, and interview) were analyzed and interpreted through both qualitative and quantitative methods.

\section{The quantitative methods}

The quantitative methods used in interpreting the results of both the test and the questionnaire were as follows:

a) The test

To answer the first research question, two tests were administered as pre-tests and post-tests. The Statistical Package for Social Sciences (SPSS) software was used to analyze data and to evaluate any statistically differences between scores of the two groups. Two independent t-tests were run for the difference between the mean scores of the experimental group and the control group on each pre-test as well as the post-test. A paired t-test was run to find the difference between the means of the scores on the following tests: the pre- and post-tests for the control group as well as for the experimental group to see if there was any difference between the performance of the subjects on the pre- and post-tests. Mean scores, standard deviations, and significance levels were conducted for all the variables of the study.

b) The questionnaire

In order to answer the second research question, the experimental groups students were asked to do a questionnaire after the treatment. The researcher adopts simple percentages and frequencies (i.e. quantitatively) technique to present the results of the questionnaire. More specifically, the results obtained from students' questionnaire were tallied, and frequencies were changed into percentages. These results were analyzed and described in terms of words and numbers.

\section{The qualitative method}

Moreover, the researcher used the narrative technique (i.e. qualitatively) in analyzing the data collected through the interview. The data collected from interview with ten students of the experimental group were analyzed qualitatively in words and sentences.

Finally, summary of major findings, conclusions and recommendations were drawn and forwarded based on the results of the study.

\section{RESULTS AND DISCUSSION}

The current study attempts to investigate the impact of using authentic listening materials on the Saudi EFL students' listening comprehension ability at Qassim University in Saudi Arabia. Two groups of students were taught in two different ways. A pre- and post-test was designed to 
British Journal of Education

Vol.8, Issue 3, pp.41-75, March 2020

Published by ECRTD- UK

Print ISSN: ISSN 2054-6351

Online ISSN: ISSN 2054-636X

investigate and compare the students' mean scores before and after the treatments and find the statistical differences. Furthermore, a questionnaire and a semi-structured interview were designed to elicit students' attitudes towards using blended learning approach in English essay writing and to provide an in-depth picture. The results of the test are presented first, and then they are followed by the results of the questionnaire and the interview.

\section{Findings related to the first research question}

In order to test the research hypotheses which leads to answer the first research question "What are the impacts of authentic aural materials on the Saudi EFL students' listening comprehension ability?", the pre/post-tests were designed by the researcher to determine whether or not there was any significant difference between the experimental and control groups regarding the listening skills. The findings of the prelpost-test are presented below.

\section{Results related to comparison of the pre-test mean scores of the control and experimental groups}

In this study, the listening comprehension pre-test was given to the participants before they started the treatment. The pre-test was aimed to assess the level of the two groups before conducting the experiment. The pre-test for both groups was conducted within the same day. To test whether "there is any statistically significant difference at $(\mathrm{P}<.05)$ level between the mean gain scores of the students of the control group (those who study the inauthentic listening materials) and the experimental group (those who study the English course using inauthentic and authentic aural materials) in the pre-test" prior to the treatment, an independent sample t-test was used. The findings showed that the mean score of the control group was 58.68 with a standard deviation of 9.146, whereas the mean of the experimental group was 56.82 with a standard deviation of 11.417 (See table1).

Table 1: An Independent T-test results for the comparison of pre-test scores between control group and experimental group in the listening skills test prior to experimentation

\begin{tabular}{|l|l|l|l|l|l|l|}
\hline Group & N. & Mean & Std. Deviation & T & DF & Sig. \\
\hline Control & 22 & 58.68 & 9.146 & .598 & 42 & .562 \\
\cline { 1 - 5 } Experimental & 22 & 56.82 & 11.417 & & & \\
\hline
\end{tabular}

Results of the pre-test in table " 1 " prove that both experimental and control group were homogeneous with regard to their listening skills. These findings affirm the first hypothesis which assumes that there is no significant difference between means of scores obtained by the 
British Journal of Education

Vol.8, Issue 3, pp.41-75, March 2020

Published by ECRTD- UK

Print ISSN: ISSN 2054-6351

Online ISSN: ISSN 2054-636X

experimental group and the control group in terms of their overall listening performance in the pre-test which means the two classes started at similar levels of listening proficiency. Therefore, the first research hypothesis is confirmed.

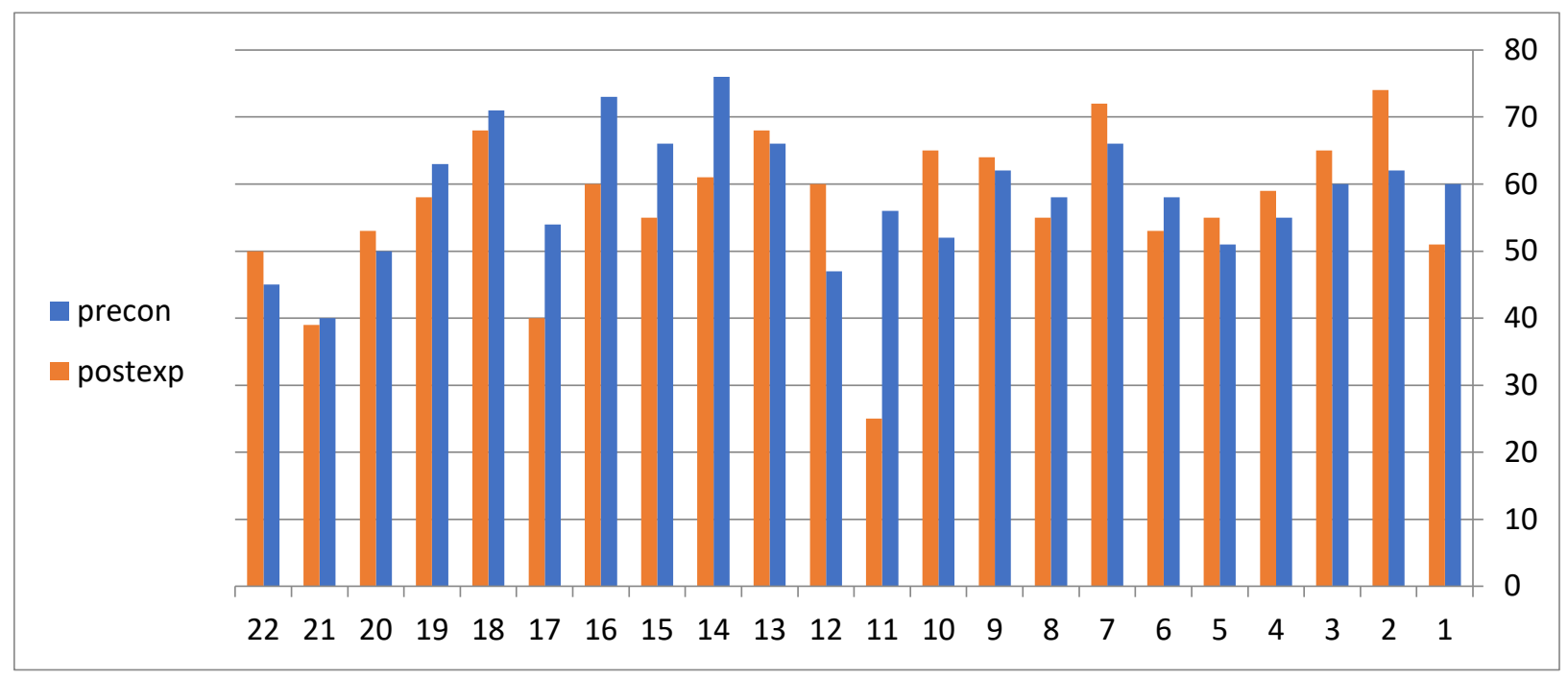

Figure (1) Comparison of Pre-test Results for the Experimental and Control groups

Based on the findings of 'figure.1.', it can be deduced that a lot of students (mean=58) had difficulty in listening comprehension. This means that they did not succeed in comprehending the authentic material. This could be clearly shown in figure 1. In the light of these findings, the subjects' low performance in the listening test may be, also, interpreted by their lack of contextual knowledge about such a text. This in turn may be due to the researcher's utilized method for presenting the authentic material, as they were asked to listen directly to the recorded text without preparing them (no warm up and, hence, no background knowledge activation). In this context, Aina (2016) indicates that it is unfamiliar to make students listen immediately to a text, as this makes it difficult for them to process the required listening skills to link what they listen to in the test material to their expectations about what to hear. Hence, they fail to use their previous knowledge.

Finally, as regards the students' constraints faced during listening to the test, nearly all the students experienced the same problem in the listening exam which is the 'speed of speech' along with pronunciation (British accent), in addition to the existence of some unknown words. 
British Journal of Education

Vol.8, Issue 3, pp.41-75, March 2020

Published by ECRTD- UK

Print ISSN: ISSN 2054-6351

Online ISSN: ISSN 2054-636X

Results related to comparison of the mean scores of the listening pre-test and post-test within the group

The differences between the pre-test results and the post-test results for each group are shown in detail in table (2). Because the two groups had two different treatments in the experiment, there was a clear improvement for the experimental group students in their overall listening performance.

To test whether "there is any statistically significant difference at $(\mathrm{P}<.05)$ level between the mean gain scores of the students of the control group (those who study the English course using the inauthentic listening materials) in pre and post-test", a paired T-test Score was conducted and the data show that there was slightly significant difference in the pre- and post-test. Table 2 shows the mean and standard deviation of pre and post-test writing overall performance for the control group.

The mean of scores of the control group in the post-test was 62.95 , whereas it was 58.68 in the pre-test. The $t$ value (-1.848) revealed that the control group has shown too little improvement. This is due to the use of the inauthentic listening materials inside the classroom where students haven't sufficient opportunities for practicing English listening. These findings are not in line with the second hypothesis which assumes that there is no significant difference between the pre- and post-test mean scores of overall listening performance for the control group. Therefore, the second research hypothesis is rejected.

Table 2. Paired Samples t-test of the Comparison of the Mean of the listening Pre-test and Post-test within the Group

\begin{tabular}{|l|l|l|l|l|c|}
\hline Group & $\begin{array}{l}\text { Pre-test } \\
\text { Mean (SD) }\end{array}$ & $\begin{array}{l}\text { Post-test } \\
\text { Mean (SD) }\end{array}$ & df & T -Test & Sig. \\
\hline Control $(\mathrm{n}=22)$ & $58.68(9.146)$ & $62.95(12.327)$ & 21 & -1.848 & .079 \\
Experimental $(\mathrm{n}=22)$ & $56.82(11.417)$ & $73.59(8.926)$ & 21 & -4.884 & .000 \\
\hline
\end{tabular}

On the other hand, the third hypothesis assumes that there is significant improvement in the experimental class' pretest and post-test scores. To compare the experimental class' pre and post test scores, a paired T-test was conducted and the data analysis shows that there was a significant improvement in students' scores in favor of the post-test, as the significance value was .000, i.e. less than 0.05 . It can be seen from the tables that there is a considerable difference between the mean scores of pretest and posttest. Specifically, students' mean score improved from about 56.82 
British Journal of Education

Vol.8, Issue 3, pp.41-75, March 2020

Published by ECRTD- UK

Print ISSN: ISSN 2054-6351

Online ISSN: ISSN 2054-636X

in the pretest to more than 73.59 in the post-test. From this finding, it can be concluded that students' performance in listening was generally improved under the impact of using authentic listening materials. This shows that the excessive exposure to the authentic material leads to an improvement in students' listening abilities.

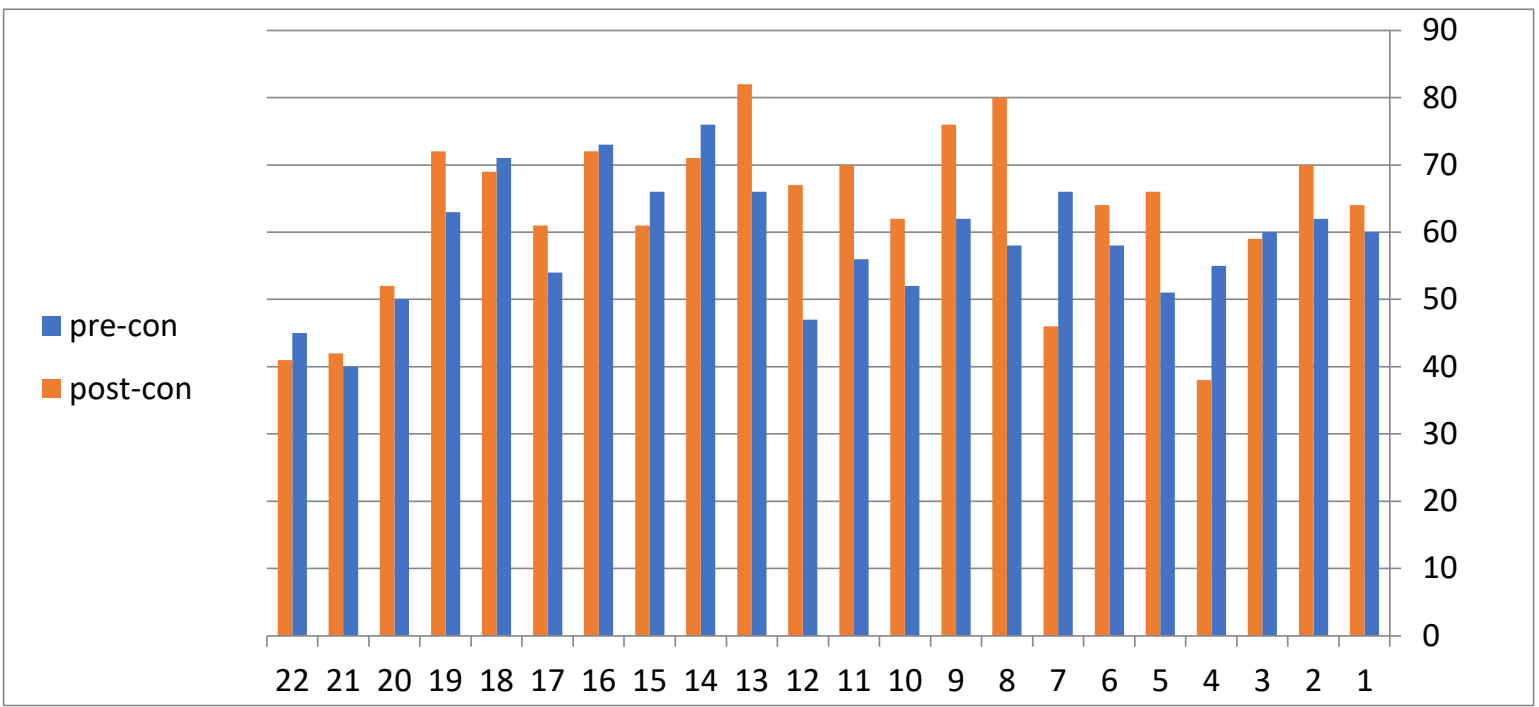

Figure (2) will show the students' total scores in the pre- and post-test for the control group.

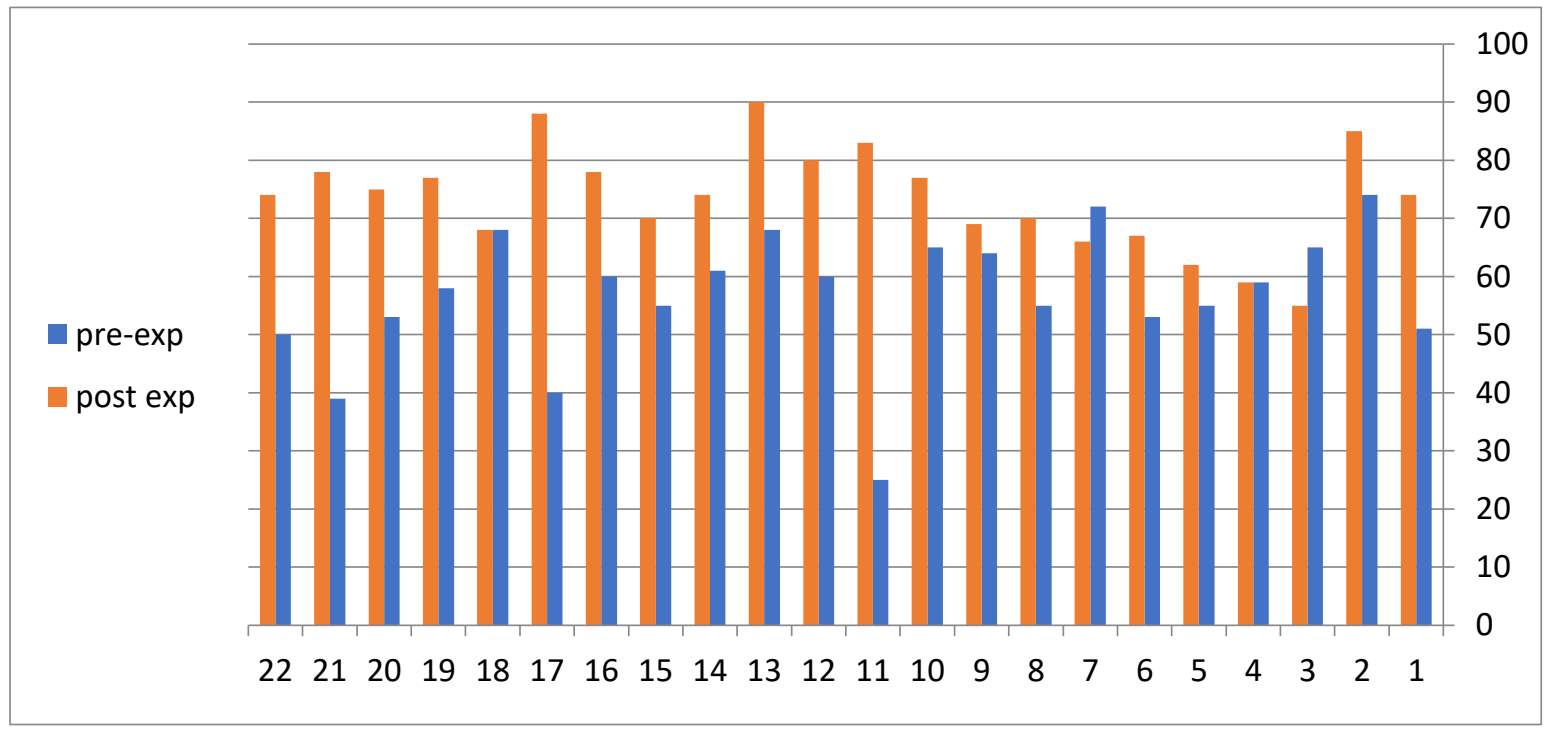

Figure (3) shows the students' total scores in the pre- and post-test for the experimental group. These remarkably high gains shown by the subjects of the experimental group on a pre-test and 
British Journal of Education

Vol.8, Issue 3, pp.41-75, March 2020

Published by ECRTD- UK

Print ISSN: ISSN 2054-6351

Online ISSN: ISSN 2054-636X

post-test comparison indicate that the experimental group' performance in listening skills has significantly improved as a result of using a combination of authentic material instruction and traditional in-class listening instruction. Figure (2) indicates that there is a slight improvement of the control group in the post test in comparison with the pretest scores, whereas figure (3) shows a remarkable improvement in the performance of the experimental group students in favor of the post test. These findings confirm the hypothesis that there is a significant difference between the pre- and post-test mean scores of the overall listening performance for the experimental group and this difference is in favor of the post-test. Therefore, the third hypothesis is confirmed.

\section{Results related to comparison of the post-test mean scores of the control and experimental groups} The training phase was followed by a listening comprehension test which was conducted on the same students, in order to assess and compare their progress regarding listening to authentic materials, before and after the treatment. To test whether "there is any statistically significant difference at $(\mathrm{P}<.05)$ level between the mean gain scores of the students of the experimental group (those who study the English course using authentic and inauthentic listening material) and of the students of the control group (those who study the same English course using the inauthentic listening material) in the post-test", an independent-samples t-test was utilized. The post-test means score of control group was 62.95 while for the experimental group was 73.59. These results indicate that the experimental group performed better than the control group in terms of their post listening scores. The reason for this high performance of the experimental group is due to the effect of using authentic listening material in teaching listening skills. These results, also, affirm the hypothesis which assumes that there is significant difference between means of scores obtained by the experimental and the control groups in terms of their overall listening performance in the post-test. Based on this, the fourth hypothesis is confirmed. Table 3 shows the mean scores for the control and experimental groups in the post-test. Figure 4 presents the raw scores of the students in the post-test.

Table 3: Comparison of Post-Test Scores between Control Group and Experimental Group in the Listening Skills Test after the Treatment

\begin{tabular}{|c|c|c|c|c|c|c|}
\hline Group & N. & Mean & Std. Deviation & $\mathrm{T}$ & $\mathrm{DF}$ & Sig. \\
\hline Control & 22 & 62.95 & 12.327 & \multirow[t]{2}{*}{-3.278} & \multirow[t]{2}{*}{42} & \multirow[t]{2}{*}{.202} \\
\hline Experimental & 22 & 73.59 & 8.926 & & & \\
\hline
\end{tabular}

According to such statistics, it can be noticed that the students of the experimental class who were taught listening comprehension by using authentic and inauthentic materials got better results on 
British Journal of Education

Vol.8, Issue 3, pp.41-75, March 2020

Published by ECRTD- UK

Print ISSN: ISSN 2054-6351

Online ISSN: ISSN 2054-636X

the listening comprehension achievement test than the students of the control group who were taught by using inauthentic materials from text-books. The effectiveness of the use of authentic materials can be seen in the sig. value in table (3). The significant value of the T test was .202, and it was less than 0.05. It means that there was a significant mean difference between experimental and control groups. So, it can be assumed that the treatment has been effective. It can be concluded that students who are exposed to authentic listening materials performed better than those students whom were introduced to simplified (graded) listening materials.

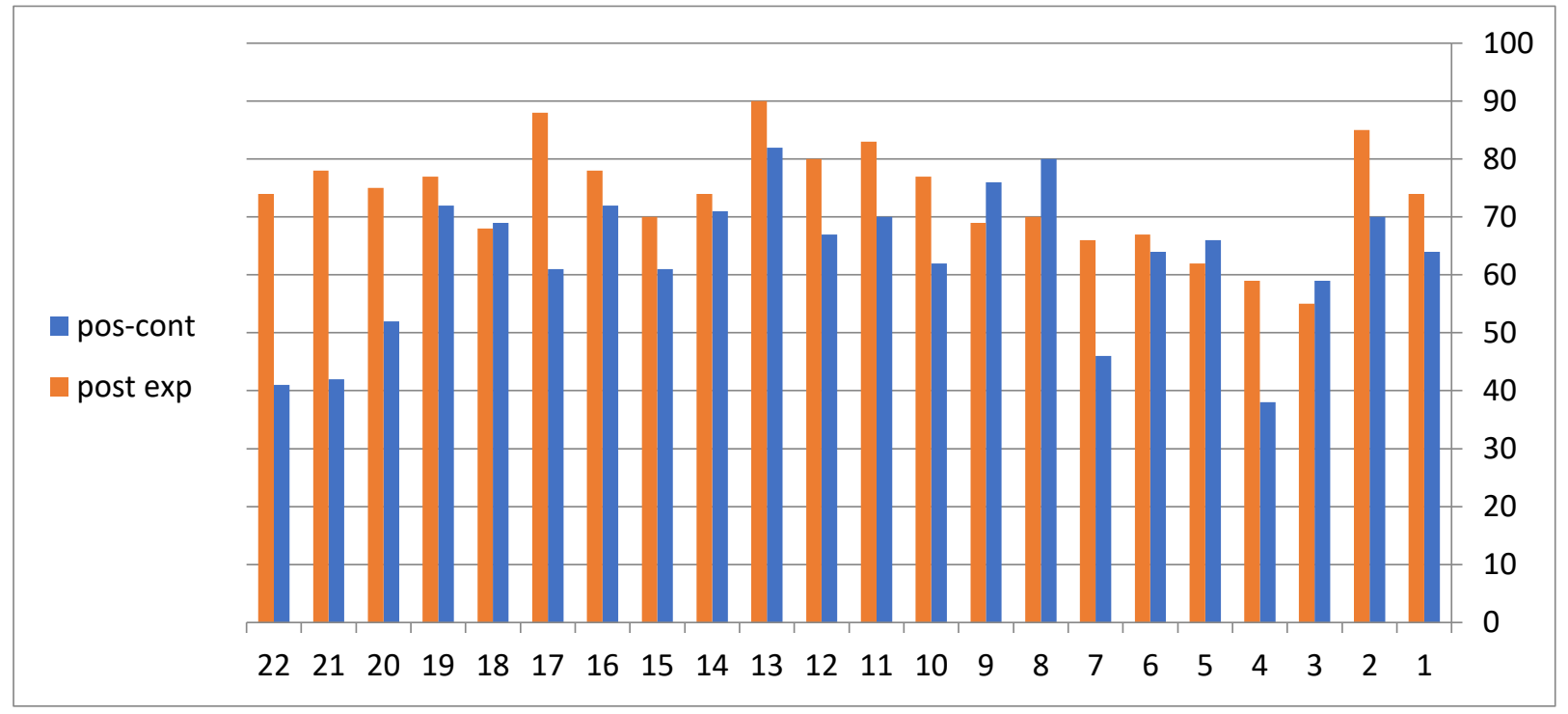

Figure (4) Comparison of Post-test Results for the Experimental and Control groups

Figure (4) indicates the remarkable difference between the scores of the experimental group students and those of the control group students. The results indicate that the experimental groups using authentic materials have improved their listening comprehension. These differences also suggest that exposing students to authentic listening materials makes them more proficient in listening comprehension. Based on the post-test results, the researcher has come to the conclusion that using authentic materials in the treatment was fruitful in enhancing the subjects' listening comprehension. This serves as evidence that authentic materials, together with properly prepared tasks, are superior to non-authentic in listening comprehension instruction. These findings are consistent with previous studies that demonstrated the positive effects of authentic input in improving students' reading and listening skills (Ghanbari et Al. 2015; Zoghi, et al., 2014; PellicerSánchez and Schmitt, 2010; Miller, 2005). Thus, this study can be considered as a contribution to the literature on the effect of authentic listening materials in language learning. 
British Journal of Education

Vol.8, Issue 3, pp.41-75, March 2020

Published by ECRTD- UK

Print ISSN: ISSN 2054-6351

Online ISSN: ISSN 2054-636X

\section{Students' attitudes and reactions toward the use of authentic listening materials in developing the listening skills}

Besides empirical data which were collected, and the statistical analyses which were conducted in the current study, the opinions from the participants of the study also provided valuable insights regarding the effectiveness of authentic listening materials. A 38-item survey concerning to the students' perception, with regard the authentic listening materials administered to the experimental group. This questionnaire was adapted from Mahsefat and Sabet (2012). Before conducting the study, it was culturally adapted and statically tested to warrant test reliability $(\mathrm{r}=0.61)$. Participants were asked to respond to four 2-point Likert-type items to measure their opinions as regards listening in English.

\section{Students' responses on the benefits they get from being exposed to the real language in authentic listening materials.}

Table 4. presents the students' responses on the beneficial effects of authentic materials on their listening skills in English. In this regard, items included from 1 up to 17 in the following table, showed the following points. To begin with item 1, more than half, 32 (74\%) of students strongly agreed that they like to listen to authentic materials to hear real spoken English.

Table 4. Experimental group's reaction to the authentic listening materials

\begin{tabular}{|c|c|c|c|c|}
\hline \multirow[t]{2}{*}{ Statements } & \multicolumn{2}{|c|}{ Agree } & \multicolumn{2}{|c|}{ Disagree } \\
\hline & N0. & $\%$ & No. & $\%$ \\
\hline 1. I like to listen to authentic materials to hear real spoken English. & 16 & 72.7 & 6 & 27.3 \\
\hline $\begin{array}{l}\text { 2. Authentic listening materials help me listen to authentic materials to } \\
\text { understand English spoken with different voices, accents. }\end{array}$ & 15 & 68 & 7 & 32 \\
\hline $\begin{array}{l}\text { 3. Authentic materials help me prepare myself for different real life } \\
\text { (actual) listening situations such as sport programs, assemblies, bus } \\
\text { station, airport, etc. }\end{array}$ & 20 & 90.9 & 2 & 9.09 \\
\hline $\begin{array}{l}\text { 4. Authentic materials help me listen to naturally pronounced English } \\
\text { words as well as intonation. }\end{array}$ & 17 & 77.3 & 5 & 22.2 \\
\hline $\begin{array}{l}\text { 5. Authentic materials help me listen and understand English spoken with } \\
\text { native speakers. }\end{array}$ & 18 & 81.8 & 4 & 18.2 \\
\hline $\begin{array}{l}\text { 6. Authentic listening materials motivate me to do more listening outside } \\
\text { class. }\end{array}$ & 16 & 72.7 & 6 & 27.3 \\
\hline $\begin{array}{l}\text { 7. I like to listen to authentic materials to expose themselves to real } \\
\text { language use that is produced for real life communicative purpose }\end{array}$ & 17 & 77.3 & 5 & 22.2 \\
\hline $\begin{array}{l}\text { 8. Authentic materials help me learn some features of spontaneous } \\
\text { speeches such as hesitations, false starts, and fillers, etc. }\end{array}$ & 20 & 90.9 & 2 & 9.09 \\
\hline $\begin{array}{l}\text { 9. Authentic listening materials expose me to a lot of vocabulary and } \\
\text { idiomatic expressions which I need in real situations. }\end{array}$ & 14 & 63.6 & 8 & 36.4 \\
\hline $\begin{array}{l}\text { 10. Authentic listening materials help me gain confidence in my listening } \\
\text { ability. }\end{array}$ & 18 & 81.8 & 4 & 18.2 \\
\hline
\end{tabular}


British Journal of Education

Vol.8, Issue 3, pp.41-75, March 2020

Published by ECRTD- UK

Print ISSN: ISSN 2054-6351

Online ISSN: ISSN 2054-636X

\begin{tabular}{|l|l|l|l|l|}
\hline 11. I am satisfied with the English authentic listening materials. & 19 & 86.4 & 3 & 13.6 \\
\hline $\begin{array}{l}\text { 12.It was interesting to practice English listening through authentic } \\
\text { listening materials. }\end{array}$ & 18 & 81.8 & 4 & 18.2 \\
\hline 13. Authentic materials make me feel frustrated. & 3 & 13.6 & 19 & 86.4 \\
\hline $\begin{array}{l}\text { 14. Authentic materials lowered the degree of anxiety when I faced new } \\
\text { situations in the target language. }\end{array}$ & 16 & 72.7 & 6 & 27.3 \\
\hline $\begin{array}{l}\text { 15.1 feel confidence when I used authentic materials in the English } \\
\text { classes. }\end{array}$ & 17 & 77.3 & 5 & 22.2 \\
\hline 16.I find authentic listening materials effective & 19 & 86.4 & 3 & 13.6 \\
\hline $\begin{array}{l}\text { 17. Authentic listening materials increase my familiarity with the use of } \\
\text { grammar rules in their original context. }\end{array}$ & 14 & 63.6 & 8 & 36.4 \\
\hline $\begin{array}{l}\text { 18. Authentic listening materials help me improve my language } \\
\text { proficiency. }\end{array}$ & 19 & 86.4 & 3 & 13.6 \\
\hline
\end{tabular}

Responding to item 2 from the above table, fifteen (68\%) students strongly agreed that they listened to authentic materials to understand English spoken with different voices, accents, which vary both socially and regionally.

In reaction to item 3, a majority of $20(90.9 \%)$ of the experimental group students agreed that they listened to authentic materials to prepare themselves for different real life (actual) listening situations. While responding to the same item, two students (9\% disagreed) and responded that they did not listen to such materials to prepare themselves for different real-life listening situations.

To item 4, about $17(77.3 \%)$ of students agreed that they listened to authentic materials to listen to naturally pronounced English words as well as intonation. But the other portion of respondents i.e. $5(22.2 \%)$ of them responded that they didn't do so. Regarding item 5, the majority of students $(81.8 \%)$ agree that authentic materials help them listen and understand English spoken with native speakers.

Responding to item 6 , more than $16(72.7 \%)$ of respondents agreed that authentic listening materials motivate them to do more listening outside class because it arouses their interest and motivations to learn the language. However, the remaining portion $(27.3 \%)$ of sample students replied that they didn't agree.

The participants' responses to the item 7 (in which students would listen to authentic materials to expose themselves to real language use that is produced for real life communicative purpose) found that $17(77.3 \%)$ of them, whereas $(22.2 \%)$ of participants disagreed with the item.

As it can be seen from the above table (in item 8), majority i.e. 20 (90.9\%) of students agreed that they listen to authentic materials to learn some features of spontaneous speeches such as 
British Journal of Education

Vol.8, Issue 3, pp.41-75, March 2020

Published by ECRTD- UK

Print ISSN: ISSN 2054-6351

Online ISSN: ISSN 2054-636X

hesitations, false starts, and fillers, etc., whereas $2(9.1 \%)$ of them indicated they disagree that they did not listen to authentic materials to learn such redundant features that occur in the speeches. As for item 9, fourteen students $(63.6 \%)$ answered that the use of authentic materials greatly helped them enrich their vocabulary, whereas 8 students (36.4\%) replied that their vocabulary didn't enrich through the use of these materials (Table 4). This finding goes in accordance with AlMusallam (2009) who reported that the majority of the students strongly agreed that authentic materials increase their knowledge of vocabulary items needed in real situations

In regards to item (10) which aims to estimate the students' confidence when they were taught English through authentic listening materials, it was found that more than three quarters of the students $(81.8 \%)$ stated that the use of authentic materials greatly enhanced their confidence (a), whereas 4 students $(18.2 \%)$ considered that these materials didn't enhance their confidence. Moreover, in item 15, seventeen students (77.3) feel confident when they use authentic materials in the English classes. As shown in Table 4, more than two thirds of the participants $(86.4 \%)$ indicate that they are satisfied with the English authentic listening materials (item 11). Moreover, a high percentage of students $(81.8 \%)$ showed that it was interesting to practice English listening through authentic listening materials (item 12). This means that the majority of the participants are interested in listening to native speakers in order to improve their levels and improve their listening comprehension since native speakers' speech is the main source of English language, whereas only about $18.2 \%$ of the participants are uninterested in listening to native speakers. In addition, only 3 students (13.6\%) see that authentic materials make me feel frustrated, whereas 19 students (86.4 $\%$ ) disagree (item 13). In item 14, most students (72.7\%) agree that authentic materials lowered the degree of anxiety when they faced new situations in the target language. In addition, less than two thirds of students $(63.6 \%)$ agree that authentic listening materials increase my familiarity with the use of grammar rules in their original context (item 17). Also, the majority (86.4\%) of students agreed that authentic listening materials help them improve their language proficiency (item 18).

In the statement number 16, the aim was to determine the effectiveness of using authentic materials in EFL classes. The results show that a high percentage of the students $(86.4 \%)$ strongly considered them very effective, whereas 3 students (13.6\%) considered authentic materials ineffective (Table 4). 
British Journal of Education

Vol.8, Issue 3, pp.41-75, March 2020

Published by ECRTD- UK

Print ISSN: ISSN 2054-6351

Online ISSN: ISSN 2054-636X

9.2.2. Students' perceptions and attitudes toward authentic and non-authentic listening material

Table 5 Students' perceptions and attitudes toward authentic material and non-authentic material

\begin{tabular}{|c|c|c|c|c|}
\hline \multirow[t]{2}{*}{ Statements } & \multicolumn{2}{|c|}{ Agree } & \multicolumn{2}{|c|}{ Disagree } \\
\hline & N0. & $\%$ & No. & $\%$ \\
\hline 19. Authentic materials are more interesting than the non-authentic ones. & 17 & 77.3 & 5 & 22.2 \\
\hline $\begin{array}{l}\text { 20. Authentic materials expose me to real-life conversations more than } \\
\text { non-authentic materials. }\end{array}$ & 16 & 72.7 & 6 & 27.3 \\
\hline 21. Authentic materials are more beneficial than non-authentic materials. & 15 & 68.1 & 7 & 31.9 \\
\hline $\begin{array}{l}\text { 22.I felt more enthusiastic when I was being taught using authentic } \\
\text { listening materials compared to when being taught using non-authentic } \\
\text { listening materials }(85 \%) \text {. }\end{array}$ & 16 & 72.7 & 6 & 27.3 \\
\hline $\begin{array}{l}\text { 23. I am actively involved in the learning when they were being taught } \\
\text { using authentic materials compared to non-authentic ones }\end{array}$ & 17 & 77.3 & 5 & 22.2 \\
\hline $\begin{array}{l}\text { 24. I enjoy learning English when using authentic listening materials } \\
\text { more than non-authentic materials. }\end{array}$ & 18 & 81.8 & 4 & 18.2 \\
\hline $\begin{array}{l}\text { 25. The inauthentic listening materials I hear in class are similar to } \\
\text { authentic materials. }\end{array}$ & 16 & 72.7 & 6 & 72.7 \\
\hline 26. Authentic materials as more satisfying than the non-authentic ones. & 21 & 95.5 & 1 & 4.5 \\
\hline $\begin{array}{l}\text { 27. I could concentrate more when I was learning English using authentic } \\
\text { materials than the inauthentic ones. }\end{array}$ & 17 & 77.3 & 5 & 22.2 \\
\hline $\begin{array}{l}28 . \text { The authentic materials I listened in class are easier than inauthentic } \\
\text { materials. }\end{array}$ & 16 & 72.7 & 6 & 27.3 \\
\hline $\begin{array}{l}\text { 29. I paid better attention to the authentic materials compared to the non- } \\
\text { authentic materials. }\end{array}$ & 15 & 68.1 & 7 & 31.9 \\
\hline $\begin{array}{l}\text { 30. Authentic listening materials are more challenging in learning } \\
\text { English than the non-authentic ones. }\end{array}$ & 16 & 72.7 & 6 & 27.3 \\
\hline $\begin{array}{l}\text { 31. I prefer to use a combination of English inauthentic and authentic } \\
\text { listening materials. }\end{array}$ & 16 & 72.7 & 6 & 27.3 \\
\hline $\begin{array}{l}\text { 32. I like the authentic listening materials because they are more varied } \\
\text { than inauthentic listening materials }\end{array}$ & 20 & 90.9 & 2 & 9.09 \\
\hline
\end{tabular}

In regards to students' perception on the use of authentic and non-authentic material, it was found that the students gave various perceptions to both authentic and non-authentic materials. In the statement number 19, students felt that the authentic materials were more interesting $(77.3 \%)$ than the non-authentic ones. We absolutely think that the term interesting/exciting always related to enthusiasm (statement number 22) since it has synonymous meaning when we looked up in an English dictionary.

Regarding item no. 20, $72.7 \%$ of students prefer using authentic materials in their listening lessons because it exposes them to real-life conversations more than non-authentic material. The same finding has been reached by Edrenius (2018) who stated that many students in his study prefer 
British Journal of Education

Vol.8, Issue 3, pp.41-75, March 2020

Published by ECRTD- UK

Print ISSN: ISSN 2054-6351

Online ISSN: ISSN 2054-636X

using authentic materials in listening lesson and that the main reason for using authentic materials in listening lessons is that inauthentic materials are different from real-life conversations. He adds that inauthentic listening materials would not adequately prepare students for interactions and conversations outside of school.

Moreover, in order to gain deeper insight into the students' attitudes, item number (21) was asked to mark which type of material students believed is more beneficial to students in English department. Two thirds of students $(68.1 \%)$ marked that authentic materials is more beneficial than the inauthentic ones. This finding is in consistent with that of Edrenius (2018) who assures that authentic materials are more beneficial than inauthentic materials. Edrenius adds that authentic materials are "more likely to be more current issues, topics etc. that might be interesting to students. He adds that "authentic materials are more suitable and can be linked to the students' program, interests and/or future working life".

Furthermore, the result of item number 22 showed that $(72.7 \%)$ students on average felt more enthusiastic when they were being taught using authentic materials compared to when being taught using non-authentic materials (77\%). In line with this finding, Berardo (2006) argued that the students' lack of enthusiasm could be caused by the language in non-authentic text which is artificial and unvaried, concentrating on something that has to be taught and often containing a series of "false-text indicators" that include: perfectly formed sentences (all the time); a question using a grammatical structure, gets a full answer, repetition of structures; very often does not "read" well. From those evidences, it could be inferred that authentic materials could make the students feel more enthusiastic than when they were being taught with non-authentic materials.

Related to item number 23, the experimental group students admitted that they were more actively involved in the learning when they were being taught using authentic materials $(88,5 \%)$ compared to non-authentic ones (77.3\%). In other words, we could say that the students' attitude manifested by the level of activity was higher when they were being taught using authentic materials.

The similar thing occurred in the item number 24, that most of the students stated that they enjoyed learning English using authentic materials (81.8\%) more than non-authentic ones. The finding was quite predictable because earlier stated that the students were actively involved when being taught using authentic materials. Also they enjoyed learning English more using authentic ones. It could be assumed that authentic materials made the students much more relax and gave them more enjoyment than in non-authentic materials when learning English. The finding might also suggest that there was a close relationship between students' active learning and the level of enjoyment toward the materials, though further analysis needed to be carried out. 
British Journal of Education

Vol.8, Issue 3, pp.41-75, March 2020

Published by ECRTD- UK

Print ISSN: ISSN 2054-6351

Online ISSN: ISSN 2054-636X

As for item 25, more than two thirds of the students (72.7\%) disagree that the inauthentic listening materials they hear in class are similar to authentic materials. This indicates that the students are more inclined to the use of the inauthentic listening materials. In regards to item number 26, the students valued the authentic materials as more satisfying $(95.5 \%)$ than the non-authentic ones. It might indicate that the students got what they needed in the authentic material. They were more relieved when being taught using authentic materials.

Similarly, on the statement number 27, when being asked about their level of concentration, it was found that students could concentrate more when they were learning English using authentic materials $(77.3 \%)$ than the non-authentic ones. It might indicate that the students' activity and concentration had a sort of relation. When the students could concentrate in certain lesson, they might be more active in following that lesson. From these two statements, related to students' "activity" and "concentration" level, the students gave higher positive attitude to authentic materials.

When being asked about the easiness of the materials to the students' need (item number 28), the students answered that the authentic materials were slightly easier $(72.7 \%)$ than the non-authentic ones. Overall, they feel that both materials were appropriate for them, it was proven by the number of the students' perception on both materials were more than 95\%.Moreover, when being asked about the attention (item 29), it was also found that the students paid better attention to the authentic materials $(85 \%)$ compared to the non-authentic materials $(68.1 \%)$. It means that the authentic materials were more interesting for the students, it attracted the students' attention more than the nonauthentic ones. In line with this fact, Dewi (2018) stated that a material had to relate to or be able to awaken the students' interest.

The similar thing occurred in the statement number 30, that most of the students stated that the authentic materials $(72.7 \%)$ were more challenging or motivating them in learning English than the non-authentic ones. To emphasize this fact, take a look at Berardo's argument (2006) which stated that authentic materials have a positive value that makes students highly motivated. As displayed in table (item 31), $72.7 \%$ of the students prefer using a combination of authentic materials and inauthentic materials, and that $27.3 \%$ preferred using only authentic materials in their listening lessons. This finding appeared to be consistent with that reached by Edrenius (2018) who confirmed that many participants in his study prefer using a combination of authentic materials and inauthentic materials. This finding also goes in accordance with that obtained by Al Muslim (2009) who affirmed that EFL Saudi college learners and teachers had positive attitudes toward the use of authentic materials in their reading classes. In fact, they indicated that an ideal reading class should use a combination of both authentic texts and textbooks. 
British Journal of Education

Vol.8, Issue 3, pp.41-75, March 2020

Published by ECRTD- UK

Print ISSN: ISSN 2054-6351

Online ISSN: ISSN 2054-636X

Finally, in statement number 32, the students valued the authentic materials as more varied (90.9\%) than the non-authentic ones. It's because of the authentic materials had many sources from our surrounding such as internet, newspaper, television, radio, etc. So, the students got more variation in their materials. For a second time, from overall questionnaires the authentic materials had higher students' positive attitude than the non-authentic ones. The finding was in line with that reached by Polat and Eristi (2019) who compared authentic materials with non-authentic materials and found that authentic materials provide students with rich learning experiences by presenting content in real contexts (Gilmore, 2011). The richness of the content in authentic materials contributes to a positive learning environment, and this affects the active participation of students in the lessons (Dewi, 2018). In countries where language learning is limited to the school or classroom context, authentic materials provide students with an opportunity to acquire rich and concrete experiences in using the target language in real life by allowing to move communication examples from real life to their learning environment (McGrath (2002). Authentic materials providing real-life examples guide students about how they can communicate when they encounter similar situations (Gilmore, 2004). Authentic materials, which are very supportive in order to get students to listen to real and natural verbal communication examples, provide them with experiences of different pronunciations, phonetic changes, emphases, speech speeds, intonations (Mohammed, 2019).

\section{Students' preferences to the types of authentic materials they would like to use in listening classes}

In this section, participants of the survey had to indicate the types of authentic materials they would like to use in listening classes. As can be seen in Table 6, the highest percentage was 90.9\%, indicating that videos are the most preferable type of listening material. This finding is consistent with the previous studies which found out that using authentic videos could be beneficial for improving the listening comprehension of learners. For example, Edrenius (2018) found that learners enjoy and subsequently learn more when watching videos for leisure. Similarly, Polat and Eristi (2019) reach to the same findings that authentic video materials reflecting the real language and communication samples, have highly effective results on the development of English listening skills and lowering the foreign language listening anxiety of students who have A1 and B1 levels of English proficiency. Khodareza and Delvand (2016) also indicated that those learners who were exposed to authentic videos showed a significant improvement in their listening comprehension skills as well as in some component parts of the communicative competence.

The order of the other types according to their preference is Videos in English (90.9\%), English Movies (81.8\%), English TV/ radio ads (77.3\%), comedy shows (72.7\%), taped short stories and novels $(68.1 \%)$, and finally dialogues and different interviews (63.6\%). This result confirms the 
British Journal of Education

Vol.8, Issue 3, pp.41-75, March 2020

Published by ECRTD- UK

Print ISSN: ISSN 2054-6351

Online ISSN: ISSN 2054-636X

findings of Mohammed (2019) research project which indicated that using English TV programs can improve the learners' listening word recognitions skills. The present study provides evidence for the positive effect of exposure to audio visual material in improving EFL students' listening comprehension. This result is similar to that reached by Ali and Celik (2019) who revealed that utilizing authentic videos is one the most influential ways in teaching listening and speaking skills in terms of relieving students from the tedium of the traditional teaching. They add that the use of visuals in the language classroom increase students' motivation and participation in the class.

Table 6. Students' preferences to use the authentic materials

\begin{tabular}{|c|c|c|c|c|c|c|}
\hline \multirow[t]{2}{*}{ Statements } & \multicolumn{2}{|c|}{ Agree } & \multicolumn{2}{|c|}{ Undecided } & \multicolumn{2}{|c|}{ disagree } \\
\hline & No. & $\%$ & No & $\%$ & No & $\%$ \\
\hline 33.I would like to watch Videos in English. & 20 & 90.9 & & & 2 & 9.1 \\
\hline 34.I would like to listen to English TV/ radio programs. & 17 & 77.3 & & & 5 & 22.7 \\
\hline 35.I would like to listen to English Movies. & 18 & 81.8 & 1 & 4.5 & 3 & 13.6 \\
\hline 36.I would like to listen to comedy shows. & 16 & 72.7 & 2 & 9.1 & 4 & 18.1 \\
\hline $\begin{array}{l}\text { 37.I would like to listen to English taped short stories } \\
\text { and novels }\end{array}$ & 15 & 68.1 & 4 & 18.1 & 3 & 13.6 \\
\hline $\begin{array}{l}38 . I \text { would like to listen to dialogues and different } \\
\text { interviews. }\end{array}$ & 14 & 63.6 & 3 & 13.6 & 5 & 22.7 \\
\hline
\end{tabular}

The questionnaire findings suggest that students reported authentic listening materials to be significantly more interesting, exciting, absorbing and increase their enjoyment, persistence to the learning task and participation in the learning task among the other listening materials. However, the overall finding revealed that the students' interest in the lesson, persistence to the learning task, enjoyment and participation in the learning task increased significantly when non-authentic listening materials were used compared to the other authentic listening materials such as the news broadcast, the telephone conversation, the interview and the announcements.

\section{The results of the interviews}

The use of follow-up interviews provided a more comprehensive picture of the participants' attitudes toward authentic listening materials. As mentioned earlier, 10 students of the experimental group participated in the interview after the treatment. The interviewees were asked five questions. Key findings arising from the analysis of their answers to the five questions are provided in the subsections below. Representative quotes are provided to better illustrate the participants 'attitudes. 
British Journal of Education

Vol.8, Issue 3, pp.41-75, March 2020

Published by ECRTD- UK

Print ISSN: ISSN 2054-6351

Online ISSN: ISSN 2054-636X

When the students were asked about their feelings towards using authentic materials on the first day of the class in their EFL listening classes, all 10 interviewees felt uncomfortable and had difficulty understanding the instructor's English on the first day of the class, but they became more relaxed afterwards. Having experienced some authentic aural materials in the classroom, the students found themselves feeling more comfortable than the time they started the class. 2 students (20\%), however, mentioned that they still felt a little uncomfortable when they encountered English outside the classroom setting.

When they were asked about their attitudes towards the use of authentic materials after the treatment, many students admitted that authentic materials were interesting because they were so excited to watch how native speakers of English spoke. They found that the listening practice they had in class assisted their listening outside the classroom by making them more self-confident and less nervous. After being exposed to authentic materials, the students recognized the authentic listening materials used in the treatment are similar to that they watched or listened to in the real world. According to the students, the language they listened to outside classroom (American or British movies, educational CDs, DVDs, etc.) was normally spoken rather rapidly, generally had regional ways of pronouncing, and sometimes contained slang words and ungrammatical features.

Regarding the types of authentic materials that they prefer in their listening course, it has been noted that all students at listening class responded that they liked many kinds of authentic materials when they studied listening course. The first preferred type of authentic materials was the videos. Here are some comments from the students:

- "I like seeing people while they are talking English because I want to learn about their mimics and gestures."

- "It helps me learn better because when I see real people talking, I learn better."

- "Each week, I look forward to watching these videos in class."

- "I wish we could watch videos in other courses as well."

- I also like watching English movies, especially those with British accent such as Harry Potter, Lords of the Rings, Pirates of the Caribbean, and Hobbits.

As can be seen in the comments from the students above, it seems that the students are pleased and satisfied with the videos they watched. One can realize that these students feel motivated to learn with visual tools as video in this case. It should also be noted that some students wish they could watch videos in other courses as well. 
British Journal of Education

Vol.8, Issue 3, pp.41-75, March 2020

Published by ECRTD- UK

Print ISSN: ISSN 2054-6351

Online ISSN: ISSN 2054-636X

\section{Learners' Perceptions on the Use of Audio Clips}

The other type which occupies the second rank according to the students' preference was audio. However, the experimental group who listened to the conversations without seeing them being acted out expressed their ideas as seen in the comments below:

- "They speak really fast and they sound different than our American teachers here."

- "I think it is better than just reading a conversation."

- "I like listening to the conversations but I wish they could speak more slowly."

- "Listening and filling in the gap activity help me to learn the phrases."

Students' responses on the listening material are varied. Although there are a few positive thoughts on listening to the conversations, all of the students complained that they find it difficult to understand the conversations.

After being exposed to authentic materials, the students recognized the difference between English they heard in class and that they experienced in English programs they watched or listened to in the real world. According to the students, the language they listened to outside classroom (American or British movies, educational CDs, DVDs, etc.) was normally spoken rather rapidly, generally had regional ways of pronouncing, and sometimes contained slang words and ungrammatical features.

Regarding the problems they face when listening to authentic materials, students had the experience, opinion, and suggestion who responded that:

"The authentic materials are both good and bad materials for me in learning English. Even though I love listening to online news in the internet, I still face many problems related to the materials until now. The first problem is that I cannot understand any topic discussed as I listen to the news. I think they sometimes talk about particular areas, habits, cultures, and discoveries that I have never heard before. The second problem is that it takes a long time to listen to the news since they are too long or even continued. Fortunately, listening to the stations and channel give me special advantages. I was not able to pronounce English words correctly years before, but now I am like a native. I do pronounce words correctly and I enjoy doing it. I have been using English like a native speaker since I can speak very well. My suggestion is listening to English news should be continued".

The respondents also confirmed that the main hindrance of the listening activities was the speed of the audio. All respondents said that they needed to hear the audio a few times before they could complete the tasks. Al-Musallam (2009) stated that teachers should be alert enough to reduce 
British Journal of Education

Vol.8, Issue 3, pp.41-75, March 2020

Published by ECRTD- UK

Print ISSN: ISSN 2054-6351

Online ISSN: ISSN 2054-636X

learners' anxiety. Besides, they should provide sufficient scaffolding to help learners succeed in their tasks and build their confidence, especially learners of lower proficiency level.

\section{-The advantages of using authentic materials}

Students thought that the advantages of using authentic materials for learning English are two folds. One of the advantages is that authentic materials present real, natural English which is suitable and appropriate for learning English. Besides, the cultures including the way they express ideas or talk about a topic are good for enhancing EFL learners' knowledge. One student reported that:

"The advantage of authentic materials for me and all of us as EFL learners is AMs from the internet are up-to date. The materials are really enjoyable that I can find the variety easily in the internet. Other materials such as movies and songs do not only entertain me, but also give me chance to learn real English from native speakers.

When asked about the listening activities, all respondents considered the use of authentic materials in listening course make it fun and interesting. Below are some of their responses:

"(I feel) happy when I see (my) teacher bringing the videos and audio clips into the class."

"It is interesting to hear something different in class."

"... different from the usual activities."

The respondents anticipated it because it was different from teacher's voice. They were more motivated when they heard something other than their teacher's voice. Motivation of learners is a vital element as it enhances learning (Dewi, 2018). Besides that, the respondents also asserted that they actually concentrated more when their teachers played the audio.

The disadvantage of authentic materials is that the materials contain complex sentence structures and choices of words. One of the students believed that the use of authentic materials reflects the way good language learners learn English. Authentic materials provide native vocabulary, grammar, and pronunciation for which good language learners expect. In order to recognize the contents of authentic materials, S6 believed that time needed was too long. So, teachers have to participate in each activity in which authentic materials are used.

However, authentic materials are disadvantageous also since they are not designed for language teaching. It causes difficulties to select appropriate ones for EFL classroom. Here are some comments from the interviewees: 
British Journal of Education

Vol.8, Issue 3, pp.41-75, March 2020

Published by ECRTD- UK

Print ISSN: ISSN 2054-6351

Online ISSN: ISSN 2054-636X

One interviewee reported that:

"The advantage of AMs for me and all of us as EFL learners is AMs from the internet are up-to date. The materials are really enjoyable that I can find the variety easily in the internet. Other materials such as movies and songs do not only entertain me, but also give me chance to learn real English from native speakers.

Finally, the interviews disclosed a surprising finding, as the researcher would have expected that students had positive attitudes toward authentic materials. The students' responses in the interviews go in consistent with the results of the listening test and the questionnaire.

\section{DISCUSSION}

According to the results, it was clear that the scores of the experimental group were statistically higher than those of control group, and the level of the experimental group on the listening comprehension improved after exposure to the authentic materials over 8 weeks, while there was no improvement in the level of the control group. Therefore, use of authentic listening materials as a supplement to traditional in-class listening instruction was significantly more effective than using traditional listening instruction alone. Teaching authentic listening materials seems to be an important factor in enhancing EFL students' listening comprehension ability. It helped enhance their listening ability and resulted in a significant improvement in their post-test scores.

Due to the findings of this study, authentic materials were found to offer a good opportunity for teaching the listening skills implicitly. Additionally, the results of this study showed that university EFL learners improved and developed their listening comprehension over 8 weeks of exposure to authentic materials.

The results of the study also showed that the experimental group achieved better than the control group, thus, using authentic materials can be regarded as an effective technique to improve the EFL learners' listening comprehension.

The responses from the questionnaire and interview regarding students' attitudes towards utilizing the authentic listening materials were wholly positive and are compatible with the findings of the post-test. The experimental group students felt interesting and confident in listening to authentic materials. The students' responses questionnaire and interview also indicated that the use of authentic listening materials had a positive effect on their attitude towards the listening instruction. It enhanced their self-esteem, motivation and sense of achievement and improvement. The students enjoyed listening course and were motivated to listen. In addition, results showed that the students highly appreciated and benefited from the authentic listening materials employed in the course in 
British Journal of Education

Vol.8, Issue 3, pp.41-75, March 2020

Published by ECRTD- UK

Print ISSN: ISSN 2054-6351

Online ISSN: ISSN 2054-636X

varying ways: it helped increase student-student and student-teacher interactions, reduce or even eliminate communication anxiety, motivate them to become (more) independent and autonomous learners, and enhance their academic English listening comprehension ability.

The findings of the current study are in line with that reached by McGrath (2002), Gilmore (2004), Al-Nafisah (2019), and Polat and Eristi (2019) who confirm that the experimental groups using authentic text had improved their listening comprehension. The former studies ascribe this improvement to the use of authentic materials. The results of the current study also go in accordance with that reached Dewi (2018), Al-Musallam (2009), Ali and Celik (2019) and Mohammed (2019) who investigated the impact of authentic materials on the development of English language, in comparison with traditional materials and textbooks or course books. Such studies affirmed that students showed positive attitudes toward the use of authentic materials stating that most of them greatly enjoyed the use of authentic materials. The analysis of the questionnaire and the interviews also revealed that authentic materials highly motivated them to wish to learn.

However, students agreed that authentic listening material does a better job at preparing learners for the interaction and communication they will face in and for real-life situations and purposes. That is, students agree with McGrath (2002) and Gilmore (2004), who argue that authentic materials make learners' accustomed to listen to native as well as foreign speakers of English, which in turn prepares learners for interactions and situations they will encounter outside the classroom. Therefore, I would argue that, despite the findings in this study, authentic materials will do a better job at preparing learners for the different types of English they will encounter outside the language-learning classroom.

To sum up, the results of the present study indicate that implementing authentic listening materials in the EFL classroom help increase the level of their listening comprehension in the post-test stage. The study also pinpoints that comprehension in EFL students improves after their exposure to authentic materials in the classroom due to the treatment, apparently. It can be concluded that to better prepare students and enable them to react accurately to the spoken language outside the classroom, it is necessary that teachers provide their students with ample opportunities to listen to samples of real language, i.e. authentic language, in the classroom. Of course, care should be taken not to confuse the findings. Non-authentic materials also benefit students to a considerable degree and the importance of real-life stuff does not exclude that of non-authentic educational materials. 
British Journal of Education

Vol.8, Issue 3, pp.41-75, March 2020

Published by ECRTD- UK

Print ISSN: ISSN 2054-6351

Online ISSN: ISSN 2054-636X

\section{CONCLUSION}

The current study aims at investigating the effect of using authentic materials on the students' listening comprehension skills. It also pinpoints EFL learners' attitudes towards the use of authentic listening materials. In this experimental study, data collection tools were pre-test - posttest, questionnaire and interview. The control group got the regular treatment of non-authentic listening materials, but the experimental group got treatment on authentic and non-authentic listening materials. Scores from the pretests and posttests provided answers to the research questions mentioned in the beginning of the study. Based on the quantitative research findings, it can be stated that although pre-test results indicated no significant difference between the means of the experimental and the control group, the means of the experimental group was found to be significantly higher than the control group according to post-test results. The findings of this study indicated that Saudi EFL students' listening comprehension appeared to have improved after they had experienced authentic listening materials in class. In addition, the results from the questionnaire revealed that all the experimental group students had positive attitudes toward providing authentic input in their classes. The reason for such an attitude was to improve students' skills and expose them to the real English language. In addition, analysis of interview indicates that EFL learners' perceptions towards the use of authentic listening materials during the eight weeks of treatment improved. Another finding reported positive responses are shown by most of the participants toward the use of authentic materials. In conclusion, it can be said that authentic materials have marked a positive effect on the attitudes of students towards English course. A conclusion for this is that authentic materials should be implemented in any foreign-language classroom.

\section{Pedagogical Implications}

Based on the conclusion above, the researcher offers some pedagogical suggestions:

1.Materials selection should be based on the learners' interest and their level of proficiency because if the content of the materials were too complicated and the texts were too long it would reduce learners' concentration and they would feel bored with the lesson and disturbed their concentration.

2.Glossary of difficult words to learn should be provided by the teacher, in order to give learners a sense of direction in their learning and help them to understand the material.

3.Learners' level should also be considered, in order to help them receive the appropriate materials that suite to their knowledge background.

4.The type of the materials could be varied with other authentic materials such as, video or movie, to let the students see directly the real English communication in daily life and also to give some kinds of imaginations through the pictures they see.

5.The materials given should adjust with the curriculum that the students are following. 
British Journal of Education

Vol.8, Issue 3, pp.41-75, March 2020

Published by ECRTD- UK

Print ISSN: ISSN 2054-6351

Online ISSN: ISSN 2054-636X

6. The teacher should play the listening material more than once, so the students would be more familiar with the native speakers' voice.

7. The teacher should check the recorded materials and test them to assure good quality of the recorded materials.

8.Lesson plan should be included in order to have good pictures of what the teacher should do in applying the materials and promoting better learning.

\section{Suggestions for further researches}

-The conclusion of this study crystalizes the need for further study into the impact of authentic materials in developing other language skills.

-Due to favorable impact of authentic listening materials, there is a need to investigate the effectiveness of different genres and modes of authentic listening materials. It also worth recommending that, the impact of different modes and genres of authentic materials investigate at elementary level.

-Next, the study can be wider in scope if it includes all possible modes and sources of authentic materials such audios, videos, from different sources, it also enjoys more pedagogical significance if compares contrasts these discrepancies and their efficiencies in developing listening skills.

-Furthermore, the impact of authentic listening materials can be investigated to see its effect on other aspect of language acquisitions such learning and intonation, stress patterns, vocabulary proficiency, incidental learning, extra linguistic factors, grammar, establishing speaking and so forth.

\section{References}

Ali, L. and Celik, S. (2019). Effectiveness of Authentic Videos in Improving Speaking Skills: An Exploration of Teachers' Perspectives. International Refereed Social Sciences Journal. Vol.-X, Issue-1, January 2019

Abdelhafez, H. \& Abdallah, M. (2015). Making It 'Authentic': Egyptian EFL StudentTeachers' Awareness and Use of Online Authentic Language Materials and Their LearningMotivation. An International Quarterly Refereed Educational Journal. Vol .1 , No. 1

Abu Hatab, A.M. 2010. The Effectiveness of a Suggested Program on Improving Listening Comprehension Achievement through Aural Authentic Materials for Al Aqsa University English Majors. M.A. Thesis. Islamic University in Gaza

Abdulhussein, F. R. 2014. Investigating EFL College Teachers' and Learners' Attitudes toward Using Authentic Reading Materials in Misan. Procedia - Social and Behavioral Sciences 136 (2014) $330-343$

Ahmad, S. Z. (2016). The Flipped Classroom Model to Develop Egyptian EFL Students' Listening Comprehension. English Language Teaching; Vol. 9, No. 9; 2016 ISSN 19164742 E-ISSN 1916-4750. Published by Canadian Center of Science and Education 
British Journal of Education

Vol.8, Issue 3, pp.41-75, March 2020

Published by ECRTD- UK

Print ISSN: ISSN 2054-6351

Online ISSN: ISSN 2054-636X

Aina, S. (2016). The Effect of Authentic Aural Materials Use on EFL Learners' Listening Skills: Case of Second-Year LMD Students at Abou Bakr Belkaid University -Tlemcen. Master in Language Studies

Alemeshet Gegreworld (2011). An Assessment of Teachers' and Students' Attitudes Twards Using Authentic Materials in EFL Classes. Unpublished M.A Thesis

Al-Musallam, E. I. (2009). College Instructors' and Learners' Attitudes to Authentic EFL Reading Materials in Saudi Arabia, unpublished thesis.

Al Asmari, A. and Gulzar, M. (2016). The Use of EFL Authentic Materials: A Gender-Line University Teachers' Perspective. International Journal of Applied Linguistics \& English Literature, International Journal of Applied Linguistics \& English Literature, Vol. 5 No. 2; March 2016

Al-Nafisah, K. (2019). Issues and Strategies in Improving Listening Comprehension in a Classroom. International Journal of Language and Linguistics. Vol. 7, No. 4, 2019, pp. 150-157.

Al-Sobhi, B. and Preece, A. (2018). Teaching English Speaking Skills to the Arab Students in the Saudi School in Kuala Lumpur: Problems and Solutions. International Journal of Education \& Literacy Studies, January 31, 2018 Volume: 6 Issue: 1

Barekat, B. and Nobakhti, H. 2014. The Effect of Authentic and Inauthentic Materials in Cultural Awareness Training on EFL Learners ${ }^{e e}$ Listening Comprehension Ability. Theory and Practice in Language Studies, Vol. 4, No. 5, pp. 1058-1065, May 2014 (C 2014 ACADEMY PUBLISHER Manufactured in Finland. doi:10.4304/tpls.4.5.1058-1065

Berardo, S. A. (2006). The Use of Authentic Materials in THE Teaching of Reading. The reading matrix 2(6). Retrieved from: http://www.readingmatrix.com/articles/

Brownell, J. (2013). Listening: Attitudes, principles, \& skills (5th ed.). New York: Routledge.

Castillo Losada, C. A., Insuasty, E. A., \& Jaime Osorio, M. F. (2017). The impact of authentic materials and tasks on students' communicative competence at a Colombian language school. PROFILE Issues in Teachers' Professional Development, 19(1), 89-104.

Bekena, B. (2011). Practices and Challenges of Teaching Listening Skills. Addis

Ababa and Debrezeit Peacekeeping English Project (PEP). Unpublished M.A Thesis

Castillo Losada, C. A., Insuasty, E. A., \& Jaime Osorio, M. F. (2017). The impact of authentic materials and tasks on students' communicative competence at a Colombian language school. PROFILE Issues in Teachers' Professional Development, 19(1), 89-104. http://dx.doi.org/10.15446/profile.v19n1.56763.

Dagim Endale (2011). An Assessment of the Practice Teaching Listening in EFL Classroom: The Case of Two High Schools in Eastern Wollega. Unpublished M.A thesis

Daniel Tiruneh (2007). An Assessment of the Practice of Teaching Listening Skills with Referenceto Kotebe College of Teachers Education: Language Students in Focus. Unpublished M.A Thesis

Dewi, R. (2018). Utilizing Authentic Materials on Students' Listening Comprehension: Does it have Any Influence? Advances in Language and Literary Studies, Volume: 9 Issue: 1 
British Journal of Education

Vol.8, Issue 3, pp.41-75, March 2020

Published by ECRTD- UK

Print ISSN: ISSN 2054-6351

Online ISSN: ISSN 2054-636X

Edrenius, R. (2018). Authentic Materials in Listening Lessons: A Study of Swedish UpperSecondary English Teachers' Attitudes toward Authentic Materials in Listening Lessons. Örebro University

Godana Menta (2011). Exploring Teachers' and Students' Attitudes towards Authentic EFL Reading Materials: Two Preparatory Schools in Wolaita Zone with Special Reference to Grade 11

Firmansyah, E. 2015. STUDENTS' PERCEPTION ON THE USE OF AUTHENTIC MATERIALS IN SENIOR HIGH SCHOOL. Bahasa \& Sastra, Vol.15, No.1, April 2015

Ghaderpanahi, L. 2012. Using Authentic Aural Materials to Develop Listening Comprehension in the EFL Classroom. English Language Teaching. Vol. 5, No. 6; June 2012

Gonen, M. (2009). The relationship between FL listening anxiety \& FL listening strategies: The case of Turkish EFL learners. Proceedings of the 5th WSEAS/IASME International Conference on Educational Technologies, July 1-3, 2009 (pp. 44-49). University of La Laguna, Spain.

Gilakjani,A.P. and Ahmadi, M.R. (2011). A Study of Factors Affecting EFL Learners' English Listening Comprehension and the Strategies for Improvement. Journal of Language Teaching and Research, Vol. 2, No. 5, pp. 977-988.

Guariento, W., \& Morley, J. (2001). Text and task authenticity in the EFL classroom. E Journal, 55(4), 347-353

Ghanbari, N. et Al. (2015). The Effect of Using Authentic Materials on Iranian EFL Learners' Vocabulary Learning. Theory and Practice in Language Studies, Vol. 5, No. 12, pp. 24592468 ,

Gilman, R. A., and L. M. Moody (1984). What Practitioners say about Listening: Research implications for the classroom. Foreign Language Annals, 17, 331-334.

Hamouda, A. (2013). An investigation of listening comprehension problems encountered by Saudi students in the EL listening classroom. International Journal of Academic Research in Progressive Education and Development,2(2), 113-155.

Herron C and Seay I (1991). The effect of authentic oral texts on student listening comprehension in the foreign language classroom. Foreign Language Annals 24(6) 487-495.

Hussein, N. and Elttayef, A. (2017) The Effect of Using Authentic Materials on Developing Undergraduate EFL Students' Communicative Competence. Retrieved from https://www.researchgate.net/publication/319007188_

Lin, L. (2002). The effects of feature films upon learners' motivation, listening, \& speaking skills: The learner-centered approach. Retrieved from ERIC database. (ED 470811)

Mamo, K. 2013. The Use of Authentic Materials in Teaching Listening Shills to College Students: The Cause of BONGA College of Teacher Education. Presented in Partial Fulfillment of the Requirements for the Degree of Master of Arts. Addis Ababa University Addis Ababa, Ethiopia

Miller, M. (2005). Improving Aural comprehension Skills in EFL, Using Authentic Materials: An Experiment with University Students in NIIGATA, Japan. Masters in Linguistics, University of Surrey 
British Journal of Education

Vol.8, Issue 3, pp.41-75, March 2020

Published by ECRTD- UK

Print ISSN: ISSN 2054-6351

Online ISSN: ISSN 2054-636X

Mohammed, W. (2019). Improving Saudi EFL Students’ Aural Oral Skills. Inter. J. Eng. Lit. Cult. 7(3): 40-48

Mutahar, A. (2017). The Influence of Using Media on Improving English Listening Skill.

McDonough, J., \& Shaw, C. (2003). Materials and Methods in ELT (2nd ed.). A teacher guide. Blackwell Publishing.

Mousavi, S. \& Iravani, H. (2012). The Effect of Authentic Versus Non-authentic Aural Materials on EFL Learners' Listening Comprehension. English Language and Literature Studies Vol. 2, No. 1

Mudra, Heri. (2014) The Utilization of Authentic Materials in Indonesian EFL Contexts: An Exploratory Study on Learners' Perceptions. International Journal of English Language \& Translation Studies. 2(2), 197-210

Khodareza, M. and Delvand, S. (2016). The Effect of Watching Authentic Videos on Improvement of Iranian EFL Learners' Listening Comprehension Ability. Indian Journal of Fundamental and Applied Life Sciences. Vol. 6 (S2), pp. 92- 100/Khodareza and Delvand

Oura, G.K. (2001). Authentic task-based materials: Bringing the real world into the classroom. Sophia Junior College Faculty Bulletin 21, 65-84.

Peacock, M. (1997). "The effect of authentic materials on the motivation". EFL Learners inEnglish Language Teaching Journal. Vol.51(2). pp.144-156

Pellicer-Sánchez, A., \& Schmitt, N. (2010). Incidental vocabulary acquisition from an authentic novel : Do Things Fall Apart? Reading in a Foreign Language, 22(1), 31-55

Polat, M. \& Erişti, B. (2019). The effects of authentic video materials on foreign language listening skill development and listening anxiety at different levels of English proficiency. International Journal of Contemporary Educational Research, 6(1), 135- 154.

Otte, J. (2006). Real Language to Real People: A Descriptive and Exploratory Case Study of the Outcomes of Aural Authentic Texts on the Listening Comprehension of Adult ESL Students

Enrolled in An Advanced ESL Listening Course. Dissertation Abstracts International, 218 B.

Sabet, M. K., \&Mahsefat, H. (2012). The Impact of Authentic Listening Materials on Elementary EFL Learners' Listening Skills. International Journal of Applied Linguistics and English Literature, 1(4), 216-229.

Zoghi, M., Moradiyan, F., and Kazemi, A. (2014). The Effects of Authentic Materials on Vocabulary Development. Retrieved January 11, 2015 from http://www.ijllalw.org/finalversion5413. 